\title{
PERANCANGAN SIMULASI SAKLAR OTOMATIS MENGGUNAKAN SENSOR PIR BERBASIS ARDUINO BERDASARKAN PERGERAKAN MANUSIA
}

\author{
Erdin Syam ${ }^{1}$, Umar Faruq Al-afifi' ${ }^{2}$, Ibrahim Bahar ${ }^{3}$, Elvin Piter ${ }^{4}$ \\ Program Studi S1 Teknik Elektro, Universitas Mulawarman \\ Fakultas Teknik, Universitas Mulawarman
}

\begin{tabular}{l} 
Informasi Makalah \\
\hline Dikirim, 28 Juni 2020 \\
Direvisi, 16 November 2020 \\
Diterima, 1 April 2021
\end{tabular}

\section{Kata Kunci:}

Penerangan Otomatis

Relay

Arduino

Sensor PIR

\section{INTISARI}

Pada era digital dan teknologi sekarang ini masih sering didapati kurangnya kesadaran dalam penerapan suatu sistem dapat menimbulkan kefatalan yang berat baik itu kecelakaan kerja maupun pemborosan energi. Dalam upaya menanggulangi permasalahan berupa pemborosan energi, dilakukan beberapa penemuan untuk menciptakan alat yang dapat menjadi solusi untuk permasalahan tersebut, alat tersebut dikategorikan dalam Instrumentasi. Dalam contoh kasus pemakaian energi listrik dalam suatu ruangan, seringkali didapati energi listrik yang terbuang percuma karena kelalaian untuk mematikan jika tidak digunakan, kasus seperti ini melahirkan inovasi penanggulangan yaitu sistem saklar otomatis yang memakai Sensor PIR sebagai pendekteksinya. Jurnal ini akan memaparkan bagaimana sistematika dari inovasi tersebut, dan untuk mempermudah, akan divisualkan berbasis simulasi menggunakan aplikasi Proteus. Inovasi ini memberikan solusi berupa perbandingan pemakaian energi dengan kasus memakai satu beban lampu 12Watt ketika tanpa menggunakan perangkat yang berarti pemakaian 24 jam $\pm 0,288 \mathrm{kwH} /$ Hari dan ketika dengan alat yaitu $\pm 0,072 \mathrm{kwH} /$ Hari bahkan bisa lebih rendah lagi tergantung intensitas pemakaian lampu dalam seharinya. Dengan data tersebut menunjukan bahwa alat ini dapat memberikan efisiensi energi yang cukup signigfikan, dan tentu dapat menghemat Tagihan listrik ketika penerapannya.

\section{Keyword:}

Automatic Lighting

Relay

Arduino

PIR Sensor

\begin{abstract}
In the digital era and technology today is still often found lack of awareness in the application of a system can cause severe fatality both workplace accidents and energy waste. In an effort to overcome the problem in the form of energy waste, a number of discoveries were made to create a tool that can be a solution to the problem, the tool is categorized in Instrumentation. In the example of the case of using electrical energy in a room, it is often found that electrical energy is wasted because of negligence to turn off when not in use, cases like this give birth to countermeasures innovation that is an automatic switch system that uses the PIR Sensor as a detection. This journal will explain how systematic the innovation is, and to make it easier, it will be visualized based on simulations using the Proteus application. This innovation provides a solution in the form of a comparison of energy usage with the case of using a 12 Watt lamp load when without using a device which means 24 hour usage \pm $0.288 \mathrm{kwH} /$ Day and when using a tool that is $\pm 0.072 \mathrm{kwH} /$ Day it can be even lower depending on the intensity of lamp usage in a day. With this data shows that this tool can provide significant energy efficiency, and certainly can save electricity bills when applied.
\end{abstract}

\section{Korespondensi Penulis:}

Erdin Syam

Program Studi Teknik Elektro

Universitas Mulawarman

JL. Sambaliung Samarinda, 75117 
Email: umarfaruq802@ymail.com

\section{PENDAHULUAN}

Perkembangan zaman telah bergerak menuju modernisasi teknologi dan berkembang secara pesat. Semua telah mengalami perubahan menjadi lebih canggih dan lebih efisien. Perubahan tersebut tak lepas dari tingkat kreativitas manusia yang kian hari kian meningkat sehingga membuat hal hal agar terkesan lebih praktis dan lebih mudah untuk digunakan. Salah satu contohnya adalah dari segi penerangan baik penerangan dalam skala besar maupun kecil yang semakin lama semakin mengalami kemajuan dari yang hanya dapat digunakan sebagai penerangan saja pada zaman dulu dengan metode atau cara yang begitu sederhana yakni menggunakan saklar hingga saat ini yang bersistem otomatis. Suatu penerangan sangat dibutuhkan oleh manusia sebagai sumber pencahayaan pengganti matahari terutama pada saat malam hari dan juga tidak menutup kemungkinan pencahayaan dibutuhkan pada siang hari jika cahaya matahari tidak terlalu terang seperti saat terjadi hujan atau pada saat cuaca mendung [2].

Pada umumnya pengaturan lampu penerangan menggunakan saklar sebagai pengatur on / off lampu tersebut yang sudah diketahui bahwa saklar ini masih menggunakan cara manual dalam pengoperasian nya. Manusia cenderung menggunakan lampu saat keadaan gelap atau saat dibutuhkan dan pastilah yang di tuju adalah saklar tersebut untuk menyalakan lampu dengan cara menggeser atau menekan tombol On sehingga lampu menjadi menyala. Ketika manusia memasuki Ruangan yang baru, tentu saja Pola pikir dari manusia tersebut adalah secara otomatis adalah mencari saklar lampu agar pencahayaan menjadi terpenuhi diruangan tersebut hal ini sudah termasuk hal yang lazim dilakukan tetapi tidak menutup kemungkinan bahwa orang akan lupa mematikan lampu itu kembali saat keluar dari ruangan tersebut. Hal ini lah yang menjadi pokok bahasan pada jurnal ini sehingga sangat menarik untuk dibahas bagaimana solusi dari kasus tersebut sehingga daya yang digunakan tidak terbuang sia sia. Jurnal ini memaparkan tentang rancangan simulasi mengenai sensor yang bekerja dengan sistem otomatis agar daya yang di gunakan tidak terbuang sehingga otomatis biaya yang di gunakan tidak besar. Cara kerja nya cukup simpel menggunakan sensor dimana sensor tersebut berfungsi sebagai pengganti saklar untuk menyalakan lampu atau sumber penerangan yang ada pada ruangan. Ketika sensor tersebut menangkap objek dalam hal ini manusia otomatis sensor tersebut mengirimkan sinyal yang akan diproses ke sumber penerangan agar lampu menyala[7].

Sensor yang digunakan pada rancangan ini bernama Sensor PIR yang memiliki prinsip kerja menangkap Radiasi Inframerah Pasif dengan ukuran gelombang radiasi tertentu yaitu antara 8-14, dan objek yaitu manusia memiliki ukuran gelombang antara 9-10 dan ini memberikan kemudahan untuk pyroelectric sensor dalam mendeteksi manusia, dengan kata lain sensor ini lah yang akan menangkap objek sehingga menjadi syarat untuk lampu agar menyala. Semisal ketika sensor PIR dilewati oleh manusia, secara otomatis Sensor PIR akan mendeteksi Gerakan gelombang radiasi yang ada manusia dan hal ini akan memberikan stimulus untuk pyroelektric dengan menghasilkan arus listrik pada sensor sebagai sinyal deteksi[4].

Selanjutnya komponen yang lain yaitu adalah Arduino. Arduino adalah Perangkat Elektronik berbasis fleksible yaitu dapat mengandalkan Hardware lain sebagai Inputannya dan Software untuk processingnya sehingga Arduino memberikan fasilitas Open-Source pada perangkatnya. Jadi arduinolah yang akan menerima atau meneruskan hasil tangkapan objek dari sensor agar lampu dapat menyala[5].

Maka dengan adanya Perancangan Sistem Saklar otomatis diharapkan permasalahan terkait kelalaian dan kurangnya kesadaran dari manusia dalam upaya untuk menghemat energi seperti tidak mematikan lampu ketika tidak digunakan, itu bisa teratasi dengan adanya Sensor PIR yang bertindak sebagai saklar dan Arduino sebagai pengendalinya.

\section{METHODE PENELITIAN}

Dalam proses perancangan Saklar otomatis digunakan metode metode agar perancangan berjalan secara sistematik dan minimum kegagalan. Dimulai dengan menjabarkan Komponen dan teknologi hingga proses pengujian sistem, Sesuai dengan tujuan awal yaitu agar alat ini nantinya dapat berjalan sesuai perencanaan dan tujuanya yaitu agar bisa menghemat pemakaian listrik jika alat ini direalisasikan nantinya.

\subsection{Teknologi Rancangan}

Sistem Saklar otomatis menggunakan beberapa Teknologi rancangan yang terangkum didalam komponen komponen yang nantinya akan menjadi bagian dari struktur alat yang akan dirancang

\section{a. PIR Sensor}

Adalah Komponen Elektronika yang dapat bekerja berdasarkan perubahan suhu yang diterima Optik dari sensor PIR berdasarkan radiasi Sinar Inframerah yang dihasilkan oleh pemancar sensor PIR sebelumnya. 


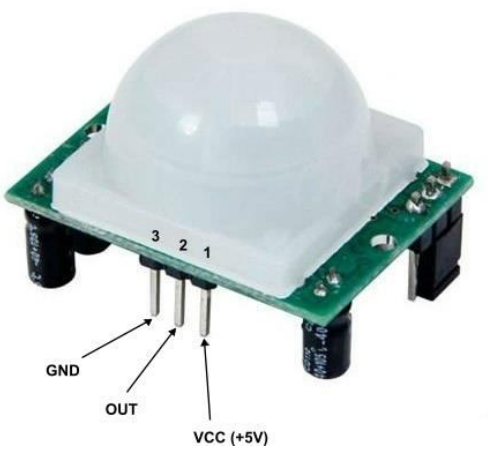

Gambar 1. Sensor PIR [7]

Sensor PIR seperti pada Gambar 2 merupakan sebuah sensor berbasiskan sinar inframerah pasif, sensor PIR akan menjadi responsif ketika ada Gelombang Radiasi yang masuk jangkauan deteksi dari sensor PIR yang terletak pada bagian Piroelektriknya. Salah satu objek dengan Ukuran Gelombang Radiasi Standar sensor PIR adalah Badan manusia yang memancarkan radiasi Pasif [2].

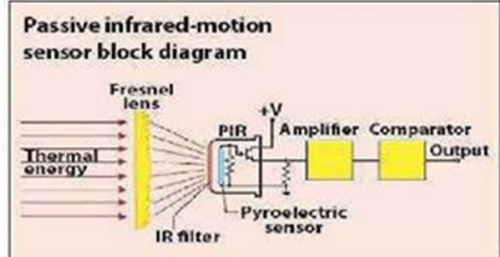

Gambar 2. Blok Diagram Sensor PIR[3]

Sensor PIR telah dibuat dengan tujuan perancangan untuk dapat responsif setiap gelombang inframerah yang sifatnya pasif dengan jarak yang telah diatur yaitu dengan ukuran gelombang 8 sampai dengan $14 \mu \mathrm{M}$, dan jika ukuran Gelombang dari objek melebihi standar yang telah diatur maka sensor tidak akan dapat mendeteksinya. Objek dalam konteks ini yaitu manusia memiliki panjaran gelombang dengan Panjang yaitu 9-10 $\mu \mathrm{M}$, atau rata ratanya 9,4 $\mu \mathrm{M}$, dan jarak ini masih dapat dideteksi oleh Sensor PIR karena sejatinya memang Sensor diciptakan dengan tujuan utama dapat mendeteksi Objek berupa manusia.

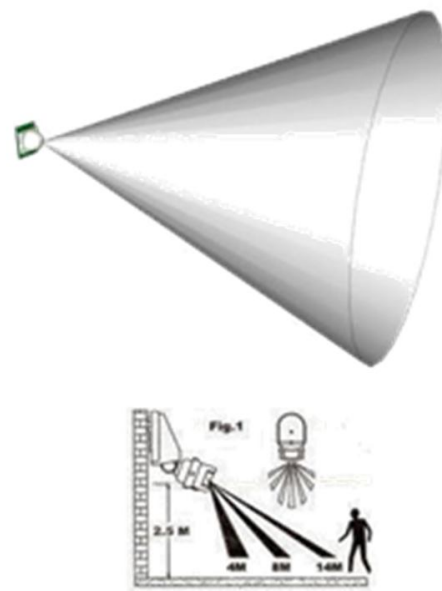

b. Arduino Uno

Gambar 3. Jarak Pancar Sensor PIR[3]

Arduino adalah Perangkat elektronika yang digunakan sebagai Pengendali Skala kecil atau microcontroller dengan basis Open-source baik dari Hardware maupun Software. Pada dasarnya Arduino sangat mudah digunakan karena Arduino dapat menerima sinyal input baik itu dari Hardware berupa sensor dan Outputnya berdasarkan control program dari Arduino itu sendiri sehingga dalam suatu sistem Arduino bertindak sebagai blok proses.

Dalam Perancangan ini selayaknya yang telah dijelaskan diatas, Arduino juga bertindak sebagai pemroses sinyal yang telah didapat dan dikirimkan oleh sensor PIR yang telah mendeteksi ada atau tidak adanya objek dalam ruangan tersebut. Sinyal deteksi dari sensor PIR nantinya akan ditindaklanjuti dengan 
memberikan sinyal data kepada pihak yang menjadi Output dari sistem, dan ini semua dapat berlaku berdasarkan program yang telah dilakukan pada awalnya melalui Port USB pada Arduino yang dihubungkan dengan media pembuat programnya yaitu Aplikasi Arduino IDE didalam PC.

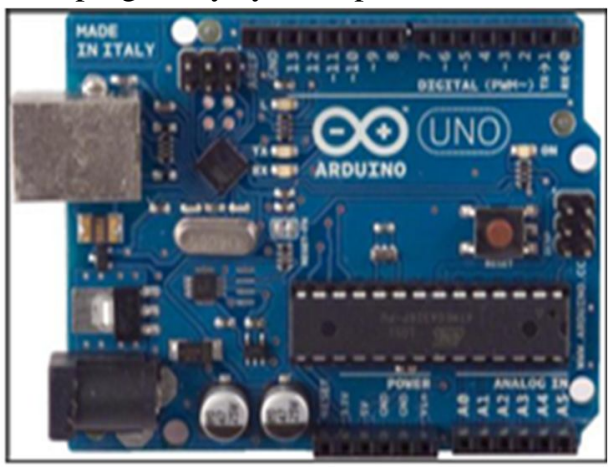

Gambar 4. Hardware Arduino[3]

c. Relay

Relay adalah jenis saklar yang dapat berkerja secara otomatis berdasarkan sinyal input program yang telah mengatur Elektromagnetik pada Relay, sehingga dapat menggerakan Kontak dari saklar untuk memberikan stimulan arus dalam jumlah yang relatif kecil agar Relay dapat mengalirkan listrik yang ukurannya relatif lebih kuat dan tinggi. Contohnya adalah ketika menggunakan Relay $5 \mathrm{~V}$ dan Arusnya $50 \mathrm{~mA}$ dengan arus yang kecil ini Relay kemudian dapat mengalirkan Listrik sebesar 220V dengan arus $2 \mathrm{~A}$

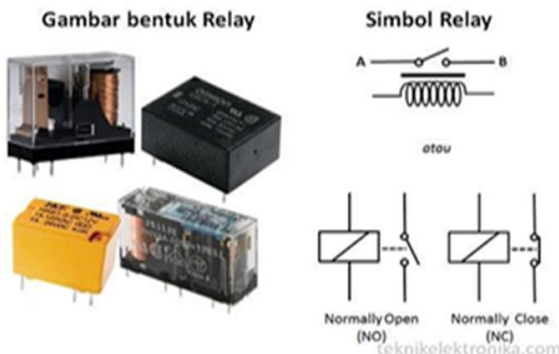

Gambar 5. Relay dan Simbolnya[3]

Komponen dasar Relay terdiri dari:

- $\quad$ Elektromagnetik (Coil)

- Armature

- Saklar Kontak

- Kawat Pegas.

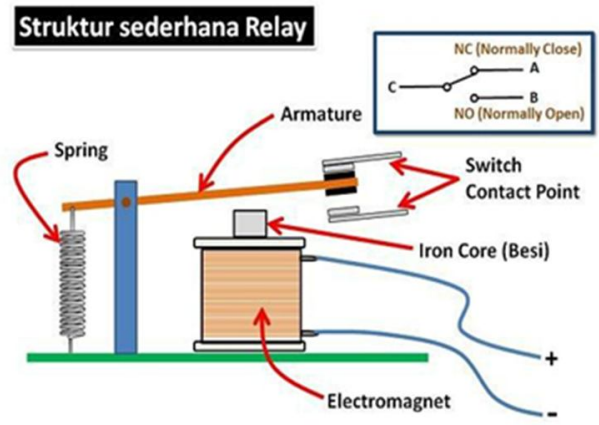

Gambar 6. Struktur Sederhana Relay[3]

Dari gambar diatas kawat melilit besi selayaknya membentuk kumparan dan memiliki fungsi untuk mengendalikan Armature tersebut yaitu dengan cara ketika besi dengan lilitan kumparan teraliri dengan energi listrik, maka seketika itu kemudian akan menjadikan besi elektromagnetik seketika yang dapat kemudian akan menarik Armature yang terbuat dari logam selayaknya sebuah magnet menarik logam 
sehingga Relay akan berposisi Normally Open (NO), posisi ini menandakan Relay bertindak sebagai saklar yang dapat mengalirkan listrik dengan arus yang cukup kecil saja.

Dalam sistem perancangan Saklar otomatis ini, Relaylah yang bertindak sebagai saklar Otomatisnya, yang mana Relay agar berposisi Normally Open ketika Sensor mendeteksi objek kemudian sinyal tersebut akan diterima oleh Arduino, dan kemudian Arduino berdasarkan Program yang telah dimasukkan ke Arduino akan memberikan sinyal perintah agar Relay berposisi menjadi Normally Open dan menghantarkan listrik ke ruangan tersebut, dalam dalam Peracangan ini indikator ruangan tersebut dialiri listrik adalah dengan menggunakan Lampu 12Watt

\subsection{Metode Rancangan}

Perancangan sistem Saklar Otomatis dengan lampu sebagai indikatornya membutuhkan Metode Perancangan, agar proses perancangan dapat dilakukan dengan sistematis dan Minim kegagalan.

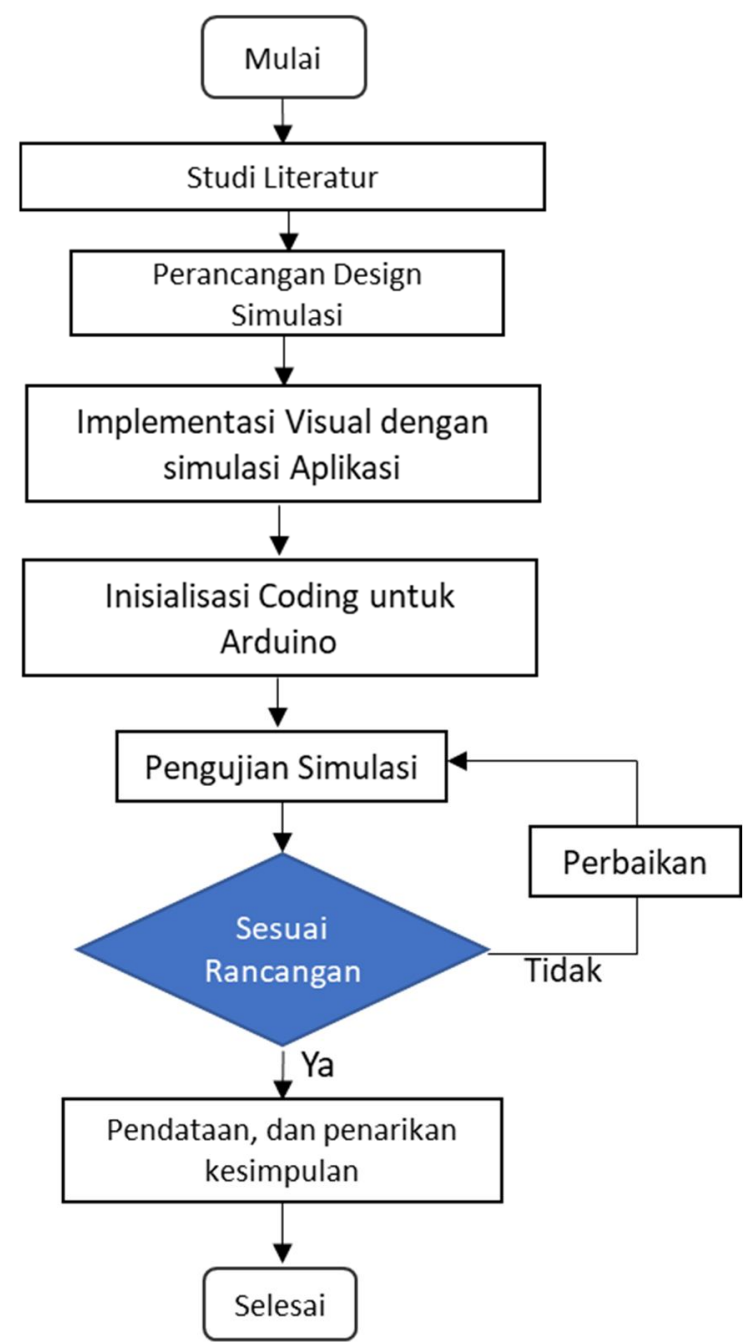

a. Merancang Design Simulasi

Gambar 8. Blok diagram Flowchart Rancangan

Perancangan Design Simulasi Sistem Saklar Otomatis dilakukan dengan memperhatikan beberapa Blok atau bagian penting dari Rancangan Penelitian yang akan dilakukan, hal ini dimaksudkan agar setiap bagian sistem dari perancangan Saklar Otomatis dalam suatu ruangan dengan indikatornya adalah sebuah lampu dapat terbentuk secara sistematis, dan memperhatikan aspek estetika dan efisiensi dari rancangan ini. Rancangan Design Simulasi dibagi menjadi beberapa bagian yaitu:

- Design Rangkaian Saklar Otomatis 


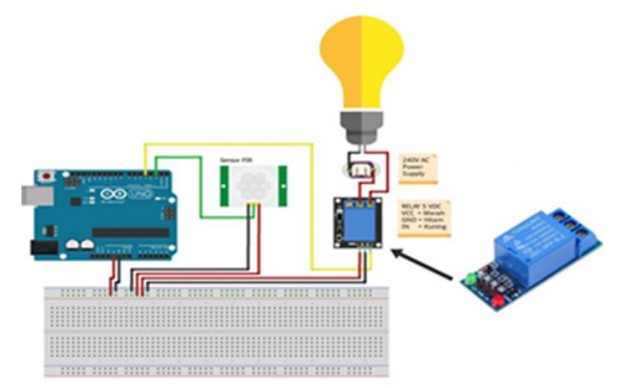

Gambar 9. Design Rangkaian Saklar[8]

Rangkaian Sistem Saklar Otomatis dengan indikator berupa Lampu diatas adalah bentuk Design secara Wiring Diagram terhadap hubungan dari antar komponen komponen penyusun sistem Saklar Otomatis

- Design Instalasi Ruangan

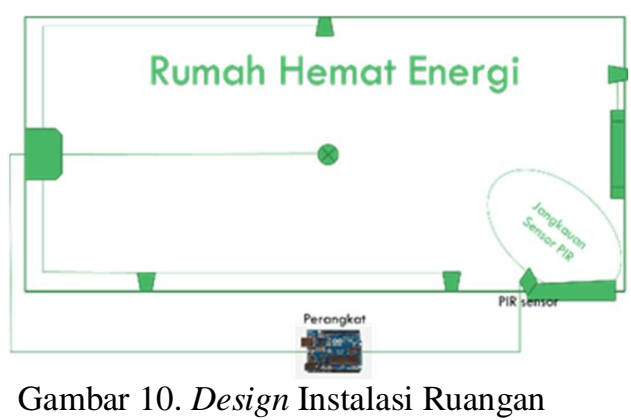

Design Instalasi diatas adalah gambaran pengaplikasian perangkat nantinya, yang Digambarkan dengan suatu ruangan lengkap dengan instalasinya kemudian dihubungkan dengan perangkat Sistem Saklar Otomatis. Hal ini dimaksudkan agar Visualisasi terhadap perancangan bisa lebih matang dan menghasilkan Analisa dan penelitian dengan data yang kongkrit dan relevan, selayaknya pemberlakuan nyatanya.

- Blok Diagram Simulasi Rancangan

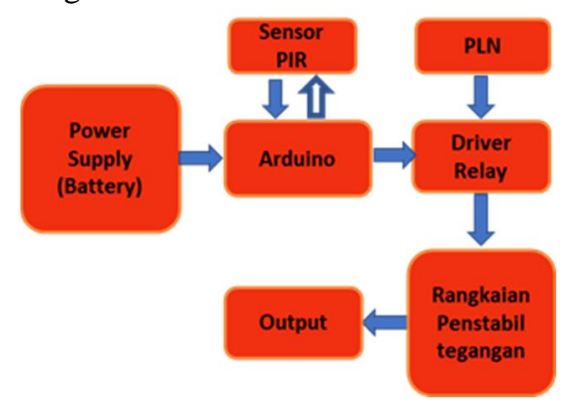

Gambar 11. Blok Diagram

Blok Diagram diatas menjadi visualisasi dari prinsip kerja dari Perangkat Sistem Saklar Otomatis, dan Prinsip kerja dari perangkat ini adalah sebagai berikut :

a. Sensor PIR akan terus $O N$ dengan menggunakan energi listrik dari Baterai

b. Sensor PIR akan standby untuk terus siap dalam mendeteksi objek didalam ruangan, dan jika objek terdeteksi maka Sensor PIR selanjutnya akan mengalirkan sinyal dalam bentuk arus listrik kepada mikrokontroller untuk dilakukan processing

c. Arduino yang telah menerima Sinyal dari sensor PIR akan melakukan proses berupa menyiapkan sinyal perintah untuk dikirimkan kepada Driver Relay, untuk membuat kontak Normally Open.

d. Relay yang telah menerima sinyal perintah, berupa arus membuat Coil pada Kumparan bereaksi dan membentuk Gaya Elektromagnetik sehingga membuat Armature menempel dengan besi dan menarik Spring, posisi ini membuat Relay dalam kondisi Normally Open dan akhirnya mengalirkan Listrik AC dari PLN. 
e. Listrik yang telah mengalir akan masuk menuju Rangkaian Penstabil Rangkaian melalui Transformator, dan disini Aliran Listrik AC yang kurang Stabil akan distabilkan di Rangkaian ini agar, Tegangan dan arusnya lebih Stabil untuk dianalisa dan Sesuai untukl Lampu Indikator.

f. Aliran Listrik yang telah stabil selanjutnya akan masuk ke IC7805 untuk dilakukan penurunan Tegangan agar sesuai dengan kebutuhan dari Indikator berupa Lampu sebagai Output, namun dalam Simulasi ini Output juga akan dipasang berupa Voltmeter dan

\section{b. Implementasi Visual dengan Simulasi}

Amperemeter, untuk melihat angka nyata dari Tegangan dan Arusnya.

Proses Implementasi Sistem rancangan Design yang telah dirancang Simulasi ini akan dibuat melalui media Aplikasi Simulasi Rangkaian yaitu Proteus, Dalam Proteus ini akan dilakukan pembuatan Simulasi dari Design Rangkaian Penerangan Otomatis.

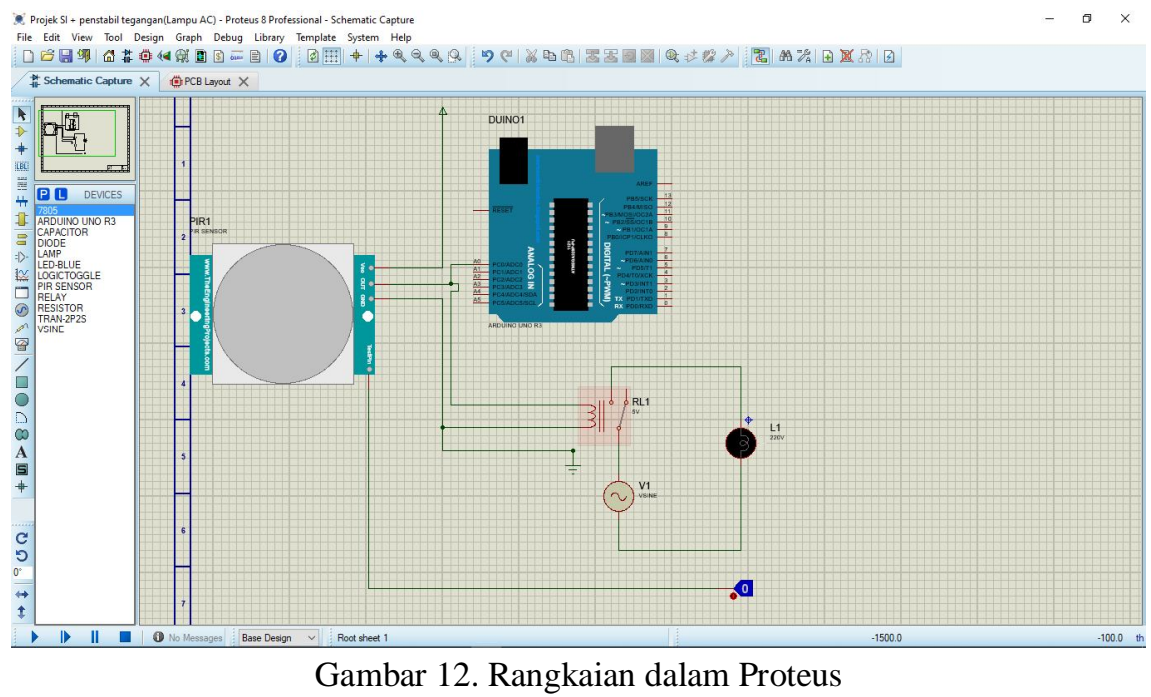

\section{c. Inisialisasi Coding Arduino}

Setelah Proses Perancangan dan Pembuatan Simulasi selesai, maka selanjutnya adalah proses untuk pembuatan Program Source untuk Arduino, agar Arduino memiliki standar Proses dalam mengendalikan perangkat Sistem Saklar Penerangan Otomatis.

Pembuatan Source Code Program Arduino dilakukan melalui media Source Code Arduino yaitu Arduino IDE, dengan aplikasi ini diatur agar Arduino dapat mengendalikan kapan arus akan dialirkan ke Relay, kemudian berapa batas Waktu setelah Relay kembali ke posisi Normally Close.

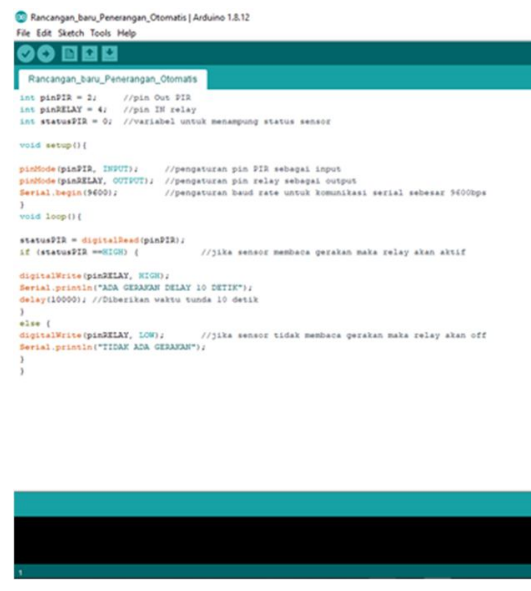

\section{d. Pengujian Simulasi}

Gambar 13. Source Code Arduino 
Setelah Perancangan dan Pembuatan selesai maka dilakukan pengujian yang diharapkan bisa sesuai dengan perancangan. Dalam proses pengujian disini akan dilakukan contoh kasus agar pengambilan data perhitungan bisa lebih mudah dan jelas.

Pada penelitian kali ini akan dilakukan simulasi dan juga pendataan berapa Output tegangan dan Arus yang dikeluarkan oleh rangkaiansetelah melewati Relay dan dengan menggunakan indikator berupa Beban Lampu 12W.

Pada Penelitian 1 ini menggunakan contoh kasus jika, dalam penggunaan ruangan dalam sehari itu adalah jam kerja yaitu dari jam 7.00 - 16.00 yang berarti totalnya adalah 10 jam/24 jam. Kemudian dalam contoh kasus ini dibuatlah perumpamaan melibatkan kehadiran objek pada jam jam tertentu dan ketidak hadiran objek yaitu pada jam 7,8 dimana ruangan Belum dipakai,kemudian jam 12 ketika Sholat Zuhur dan jam 16 yaitu jam pulang kerja.

Pada penelitian 2 ini merupakan penelitian yang dimaksudkan sebagai pembanding penelitian 1, yaitu pada penelitian 2 ini terdapat simulasi dengan tidak melibatkan objek dan sensor apapun, sehingga dapat dianalogikan bahwa didalam ruangan Ketika penelitian 2 ini, lampu akan terus menyala non-stop selama 24 jam sehari, walaupun ada atau tiadanya objek didalam ruangan tersebut

Kemudian spesifikasi lampu yang akan digunakan adalah sebagai berikut:

- $\quad$ Spesifikasi Lampu

$$
\mathrm{V}=220 / 240 \mathrm{~V}
$$

$\mathrm{W}=12 \mathrm{~W}$

\section{e. Pengambilan data}

Setelah dilakukan pengujian selanjutnya akan dilakukan pengambilan data dan perhitungan untuk penyesuaian data berdasarkan hasil simulasi, yang mana data data yang

- $\quad$ Pemakaian Daya per jam

Adalah perhitungan pemakaian daya per jam, setelah jumlah daya dengan satuan Watt akan dikonversi menjadi Daya dengan Satuan internasional yaitu kilo Watt hour(kWh) dengan cara dibagi dengan 1000 .

$$
\mathrm{W}=\frac{P}{1000} \times t
$$

$$
\mathrm{W}=\text { Energi listrik(Wh atau Joule), } \mathrm{P}=\text { Daya Daya(Watt), } \mathrm{t}=\text { Waktu(s) }
$$

- $\quad$ Pemakaian Daya Per hari

Adalah perhitungan berdasarkan pengunaan Energi listrik per jamnya di kalkulasikan dengan lama pemakaian dalam sehari.

- $\quad$ Perbandingan Penelitian 1 dan 2

Pendataan berupa membandingkan hasil pengujian simulasi ketika memakai perangkat Sistem Saklar otomatis yang akan dibandingkan datanya dengan ketika Ruangan tidak memakai perangkat tersebut, hal ini dimaksudkan agar memperlihatkan bahwa alat ini dapat memberikan solusi terhadap permasalahan pemborosan penggunaan energi listrik karena kelalaian.

\section{HASIL DAN PEMBAHASAN}

Berdasarkan pengamatan dan penelitian yang telah dilakukan dari model simulasi Sistem penerangan Otomatis berbasis Arduino didalam suatu ruangan percobaan maka didapat data data Rancangan yaitu Pengujian sensor PIR dilakukan untuk mengontrol penerangan didalam ruangan dengan cara mendeteksi keberadaan manusia.

Dalam penelitian ini juga ditambahkan dan kemudian juga memakai Beban Lampu sebagai indikator keluaran dalam ruangan dan juga sebagai patokan dalam pengambilan data. Setelah dilakukan pengujian maka didapatlah data data sebagai berikut.

Tabel 1. Pengujian Menggunakan Sensor PIR.

\begin{tabular}{cccc}
\hline Waktu $(J a m)$ & Tegangan $(\mathbf{V})$ & Daya $(\mathbf{W})$ & Ket \\
\hline $\mathbf{0 0 . 0 0 - 0 6 . 0 0}$ & 0 & 0 & Mati \\
$\mathbf{7 . 0 0}$ & 0 & 0 & Mati \\
$\mathbf{8 . 0 0}$ & 0 & 0 & Mati \\
$\mathbf{9 . 0 0}$ & 0 & 12 & Menyala
\end{tabular}




\begin{tabular}{cccc}
$\mathbf{1 0 . 0 0}$ & 220 & 12 & Menyala \\
$\mathbf{1 1 . 0 0}$ & 220 & 12 & Menyala \\
$\mathbf{1 2 . 0 0}$ & 0 & 0 & Mati \\
$\mathbf{1 3 . 0 0}$ & 220 & 12 & Menyala \\
$\mathbf{1 4 . 0 0}$ & 220 & 12 & Menyala \\
$\mathbf{1 5 . 0 0}$ & 220 & 12 & Menyala \\
$\mathbf{1 6 . 0 0}$ & 0 & 0 & Mati \\
$\mathbf{1 7 . 0 0 - 2 3 . 5 9}$ & 0 & 0 & Mati \\
Rata-rata & 220 & 12 & \\
\hline
\end{tabular}

Untuk mengetahui Pemakaian daya per jamnya dengan satuan Internasional yaitu :

$\mathrm{W}=\frac{P}{1000} \times t$

$\mathrm{W}=\frac{12}{1000} \times 1 \mathrm{jam}$

$\mathrm{W}=0,012 \mathrm{kWh}$

Berdasarkan Perhitungan diatas maka Pemakaian energi listrik per harinya yaitu selama 6 jam dalam seharinya adalah :
$\mathrm{W} / \mathrm{Hari}=$
$0,012 \mathrm{kWh} .6 \mathrm{~h}$
$\mathrm{W} / \mathrm{Hari}=$

$$
0,072 \mathrm{kWh}
$$

Tabel 2. Pengujian Tanpa Menggunakan Sensor PIR

\begin{tabular}{cccc}
\hline Waktu (Jam) & Tegangan(V) & Daya(W) & Ket \\
\hline 00.00-23.59 & 220 & 12 & Menyala \\
Rata- rata & 220 & 12 & - \\
\hline
\end{tabular}

Pemakaian daya per jamnya pada pengujian dengan tanpa menggunakan perangkat Sistem Penerangan Otomatis dengan Sensor PIR, ketika terdeteksi objek adalah

$$
\begin{aligned}
& \mathrm{W}=\frac{P}{1000} \times t \\
& \mathrm{~W}=\frac{12}{1000} \times 1 \mathrm{jam} \\
& \mathrm{W}=0,012 \mathrm{kWh}
\end{aligned}
$$

Dan pemakaian per jam, jika dikalkulasikan dengan pemakaian non stop/hari nya yaitu 24 jam maka pemakaiannya adalah:

$\mathrm{W} / \mathrm{Hari}=0,012 \mathrm{kWh} .24 \mathrm{~h}$

$\mathrm{W} / \mathrm{Hari}=0,228 \mathrm{kWh}$

Dari pendataan berdasarkan pengujian diatas maka dilakukanlah perbandingan antara ketika menggunakan Perangkat Sistem Penerangan Otomatis dan ketika ruangan Tidak menggunakan perangkat Sistem Penerangan Otomatis berbasis saklar.

Dengan perbandingan berikut akan terpampang dengan jelas bagaimana Penggunaan energi ketika dengan atau tanpa menggunakan Perangkat Sistem Penerangan otomatis, yang dengannya menunjukkan efisiensi yang baik dan penghematan yang cukup jika menggunakan Perangkat ini.

\begin{tabular}{cccc}
\hline Kondisi Ruangan & Tegangan(V) & Daya $(\mathrm{W})$ & E.Listrik(kWh) \\
\hline Menggunakan Sensor PIR & 220 & 12 & 0.072 \\
Tidak Menggunakan & 220 & 12 & 0,228
\end{tabular}

Dari hasil perbandingan pengujian di atas dapat dilihat bahwa ketika menggunakan sensor PIR energi listrik yang terpakai dalam sehari selama 6 jam adalah 0,30898 $\mathrm{kWh}$ dan ketika menggunakan sakelar manual adalah 0,4450 kWh. Dapat disimpulkan bahwa ketika menggunakan sakelar manual energi yang terpakai lebih besar dari menggunakan sensor PIR.

\section{KESIMPULAN}

Berdasarkan penelitian dan pengujian serta pendataan diatas, maka ditarik beberapa kesimpulan yaitu:

a. Pengontrolan lampu akan terputus secara otomatis jika tidak ada mendeteksi manusia.

b. Dari Pengujian Simulasi yang telah dilakukan Perangkat ini memiliki Respon terhadap Gerakan manusia yang memancarkan Infrared Pasif, dan hal ini menjadi dasar perangkat ini mengendalikan Penerangan atau bertindak sebagai saklar Otomatis ketika mendeteksi objek sesuai dengan jarak yang telah diatur

c. Sistem ini dapat menjadi Solusi tepat terhadap kelalaian Manusia yang kadang lupa untuk bertanggung jawab mematikan aliran listrik ketika tidak digunakan dalam suatu ruangan sehingga hal ini dapat menjadi solusi untuk pemborosan Listrik karena tidak terpakai.

d. Setelah dilakukan Simulasi dengan menggunakan beban berupa lampu 12W, didapatlah pemakaian listrik ketika menggunakan Sensor PIR yaitu 0,072 kwH selama 6 jam sehari, dan pemakaian listrik 
sebesar 0,228 kwH selama 24 jam dalam sehari, dan dari data tersebut menunjukan penghematan yang didasari oleh rentang waktu pemakaian yang dikontrol penuh oleh sensor PIR.

\section{UCAPAN TERIMA KASIH}

Terima kasih diucapkan kepada seluruh pihak yang telah membantu Jurnal rancangan ini untuk terealisasi, yaitu kepada :

a. Allah SWT, yang selalu memberikan segalannya, Kesempatan dan waktu luang untuk terus belajar, menuntut ilmu serta menjadi lebih baik

b. Orang tua, yang selalu membersamai dan mendukung dalam suka maupun duka

c. Prodi dan dosen Teknik Elektro yang telah memberikan wadah dan bimbingan dalam upaya mencerdaskan kehidupan bangsa

d. Ir. Rani Alham S.pd.,M.T selaku Dosen Mata Kuliah Sistem Instrumentasi, yang tidak henti hentinya memberikan dukungan dan dorongan untuk terus berkarya dan bekerja keras dalam upaya memajukan diri dan masa depan.

e. Teman teman Elektro 2018, dalam kebersamaan menggapai cita cita dan tujuan

f. Dan seluruh pihak yang telah membantu secara dukungan dan moril yang tak bisa dijabarkan satu per satu.

Semoga Allah selalu menjaga kita semua, mempermudah segala urusan kita, dan menjadikan kita semua bertetangga di Syurga-Nya kelak.

\section{DAFTAR PUSTAKA}

[1] Sutono., "Perancangan Sistem Aplikasi Otomatisasi Lampu Penerangan Menggunakan Sensor Gerak dan Sensor Chaya Berbasis Arduino".,Universitas Komputer Indonesia., 2014.

[2] Titi Andirani, M.Hidayatullah, M.Ikbal., "Rancang Bangun Sistem Keamanan Menggunakan Sensor Passive Infrared Dilengkapi dengan Kontrol Pendingin Ruangan Berbasis Arduino Uno dan Real Time Clock”., Universitas Teknologi Sumbawa., 2017.

[3] Puji Jihanisyah Putri., "Perancangan Sistem Otomatis Lampu Menggunakan Sensor PIR berbasis Arduino"., Universitas Sumatera Utara., 2016.

[4] Wildian, Osna Marnita., "Sistem Penginformasi Keberadaan orang didalam Ruang Tertutup dengan Running Text Bebasis Mikrokontroller dan Sensor PIR"., Universitas Andalas., 2013.

[5] Andri Kurniawan, Bayu Rukmana Jati, Nada Ayunita Sunarto., "Smarthome Energi Saver dengan Penggabungan Sensor LDR, PIR, Suara, dan Temperature untuk mempresentasikan Kondisi Ruangan Sebagai Perangkat Penghemat Energi Listrik yang Digunkan dalam Masyarakat”., UIN Syarif Hidayatullah., 2018.

[6] Andreas Syah Lamtari, Syaifurrahman, Dedy Suryadi., "Rancang Bangun Penerangan Otomatis Berdasakran Gerak Tubuh Manusia"., Universitas Tanjungpura.,2016.

[7] https://abudawud.wordpress.com/2018/06/02/mengenal-sensor-pir-passive-infrared/., Diakses pada 16 Juni 2020

[8] https://teknisibali.com/cara-program-sensor-pir-arduino/., diakses pada 13 Juni 2020 